\title{
Matching Office Information Systems (OIS) Curriculum To Relevant Standards: Students, School Mission, Regional Business Needs, and National Curriculum
}

\author{
Arlene August \\ august@pace.edu \\ Judy Caouette \\ 75333.502@compuserve.com \\ Pace University, USA
}

\begin{abstract}
This paper examines the process and outcome of a major curriculum update for the Office Information Systems (OIS) major in the Office Information Systems Department in the School of Computer Science and Information Systems (CSIS) at Pace University. The curriculum was updated to better prepare our students for success as end-user specialists in today's flattened organizations. The changes made were based on modules recommended from the Office Systems Research Association (OSRA)--recommendations that were both reliable and valid. OSRA's national curriculum was flexible enough to allow us to incorporate regional business demands as well as adhere to CSIS's mission statement. The success of this curriculum, now two years old, is measured by the success of our graduates (B.Sc. degree) in obtaining meaningful employment.
\end{abstract}

Keywords: Office Information Systems (OIS) curriculum, Organizational and End-user Information Systems (OEIS) curriculum, information technology (I/T) curriculum

\section{Introduction}

Need for Productivity. The need for greater productivity requires employees to work smarter with fewer layers of people in a collaborative environment. Sleeker, flatter organizations--supported by rapidly emerging technologies--require productive, agile workers able to work collectively as well as individually. The skills and attitudes that worked in the past no longer fit these flattened, information-intensive companies.

"The agile business ... has explicit processes for changing; ... . like 'learning, innovation, and re-engineering.' These change processes are managed with the same commitment given to operational processes" (Robinson, 1996, p. 19). Because agile businesses require a new and different type of employee in the workplace, universities have had to respond to these changes in the classroom by emphasizing teamwork, cooperation, and collaboration--mirroring today's workplace trends. This

Material published as part of this journal, either on-line or in print, is copyrighted by the publisher of Informing Science Permission to make digital or paper copy of part or all of these works for personal or classroom use is granted without fee provided that the copies are not made or distributed for profit or commercial advantage AND that copies 1) bear this notice in full and 2) give the full citation on the first page. It is permissible to abstract these works so long as credit is given. To copy in all other cases or to republish or to post on a server or to redistribute to lists requires specific permission and payment of a fee. contact Editor@gise.org to request redistribution permission. emphasis on introducing human relation skills into the course of study is new to most curriculums. As a result, instructors are required to move away from the traditional stand-up and lecture method; instead, they are becoming "facilitators" (Merriam and Brockett, 1997, p. 41), advisors, and coaches of learning in an interactive environment. This change also puts new responsibilities on students as learners. They are now active partners in their own learning process.

Because of the changes that are sweeping across corporate America, universities have had to respond with curriculum modifications preparing students for a new type of workplace. This is especially true in colleges and universities with schools or departments of Office Information Systems (OIS).

At Pace University the OIS Department resides within the School of Computer Science and Information Systems (IS) where it is one leg of a triumvirate consisting of Computer Science (CS) -- concentrating on hardware and software engineering; Information Systems (IS) -- focusing on business and manufacturing transaction systems, operations management, enterprise data management, and networking; and OIS -applying a socio-technical focus to the end user in desktop computing and work group performance (Regan, 1996, p. 5). 
Impact of technology. Historically, mainframe computers were the backbone of large, forward-thinking, informationintensive organizations. As time passed, personal computers (PCs) found their way onto desktops, giving greater power with ease to end-users. Today, employees are linked through distributed networks, taking advantage of the strength mainframes offered, coupled with the benefits of user-friendly PCs. Workers are being provided with faster, easier, and less costly ways of managing and controlling their own information along with acquiring access to many new types of technologies: multimedia, group support systems, video conferencing, the Internet/WWW (Jenkins, M., 1995), and image systems. These emergent (often interactive) technologies are being accessed at lightning speeds never before dreamed possible by end-users. End-users are those employees who use technology to carry out their jobs as compared to employees whose jobs are technology (Regan \& O'Connor, 1994, p. 670). The tools not only support individual and work group processes, but also contribute to individual and overall organizational performance (Regan, 1996, p. 2).

\section{Pace University OIS Curriculum Chal- lenge}

CSIS Mission Statement. Because of its residence in CSIS, the OIS Department reflects the school's mission aspiring to "innovative leadership in preparing men and women for meaningful work, lifelong learning, responsible participation in a new and dynamic information age" "... programs are responsive to the rapid pace of technological development" (Pace University, 1996-1998, Undergraduate Catalog, p. 75).

Regional Business Requirements. As Pace University is situated in both Manhattan and Westchester County, the OIS Department responds to the employment demands of these locations--potential employment sites for our graduates. In a 1992 study by August focusing on OIS career opportunities in the region, most respondents (managerial, technical, and supervisory personnel) wanted future employees to have some technical training. This training included knowledge of operating systems, any programming language, LAN concepts, networking management, telecommunications, trouble-shooting abilities, as well as a strong skill set in current desk-top applications. These respondents also wanted employees to stay abreast of emerging technologies (p. 107). Additionally, on the soft side, " ... the need for decision-making and problemsolving skills along with communication skills, customerrelation skills, skills in dealing with people, and skills in the team approach" was critical (p. 106).

\section{Choice of national curriculum selection}

The CSIS School is unique in having three departments under the same roof providing students with a selection of majors to study. The Computer Science (CS) curriculum is based upon algorithms and data structures, the principles of programming languages, computer architecture and theoretical foundations. It is accredited by the Computer Science Accreditation Commission (SCAC). The Information Systems (IS) curriculum is designed to provide students with current technical skills as well as the knowledge of those information systems concepts that remain constant in the face of technological change. The Office Information Systems (OIS) curriculum takes a behavioral approach, preparing graduates to use the right information technologies for the right task at the right time supporting work-group processes and employee performance linked to organizational goals in the collaborative work environment. It differs from the other programs in that its emphasis is on a "quick response, ad hoc, personalized, and prototype development" (Regan, 1993, p. 4) in a rapidly changing business and technological environment.

Because of the regional business demands discussed above, the OIS faculty met over a two-year period studying the possibility of updating our curriculum to reflect the major technological changes, as well as the growing significance placed on soft skills. Various curricula were evaluated using assorted resources (Davis, et al, September, 1995; Davis, et al, 1995; Fisher \& Schwartz, 1995; Longenecker \& Feinstein, 1995; and O'Connor, 1996). In reviewing earlier Association for Computing Machinery (ACM) and Data Processing Management Association (DPMA) models, we found that they appeared comparable. Both included a more technical and traditional approach focusing on computer concepts, systems analysis and design, database design, and IS projects. The newer IS '95 model seemed broader--with emphasis on some behavioral skills, creativity, and effective interaction with clients. However, it did not address ergonomic workplace issues, emphasize emerging technologies, require an internship, or give much attention to the soft skills. The updated OSRA curriculum, on the other hand, broke new ground in introducing a sociotechnical approach. Understanding that there must be an alliance between the end-users (the social system) with the tools and techniques they use (the technical system), course requirements focused on the end-user and included more human-relation skills than either the ACM or DPMA models (Caouette \& Lutz, 1996, p. 33). In this curriculum, importance is placed on understanding how technology can advance indi-

${ }^{1}$ DPMA since changed its name to the Association of Information Technology Professionals (AITP). 
vidual and work group performance along with behavioral competencies such as group dynamics and team work, job redesign, meeting facilitation, ergonomics, ethical considerations, organizational training and development, and managing technological change. Additionally, the individual modules included practice in all the soft skills--giving students the opportunity to cultivate and rehearse their verbal, written, and presentation/platform skills.

Following the national curriculum validation model, the OIS faculty also held focus groups, discussions, and interviews with representative stakeholders--business professionals, students, administrators, the University's Co-op and Career Develop- ment Program, and faculty in other departments. From the data gathered, we chose the OSRA curriculum.

\section{The OSRA Curriculum}

National Curriculum. OSRA was founded in 1981 by a team of business practitioners and educators who designed the original 1986 national curriculum preparing four-year undergraduates for a rapidly expanding technological workplace (Thomas, 1986, p. 59). That curriculum was adopted by over 65 universities and colleges nationwide (O'Connor, 1996, p. $18)$.

In 1996, the curriculum, with the new title of Organizational
OEIS Model Curriculum
OEIS 1 (Concepts are introduced)

Pace University OIS Curriculum

OIS 210 Word processing Applications for the Microcomputer (3 credits)

OIS 211 Spreadsheet Applications for the Microcomputer (3 credits)

OIS 212 Database Management for the Microcomputer (3 credits)

OIS 214 Microcomputer Operating Systems (3 credits)

OEIS 2 (Solutions)

OIS 213 Multimedia Emerging Technologies for Business $2 / 3$

Solutions ( 3 credits)

OEIS 3 (Planning and Design)

OIS 220 End-user Information Systems: Planning and Design (3 credits)

OEIS 4 (Implementation and Evaluation)

OIS 321 End-user Information Systems: Implementation and Evaluation (3 credits)

OEIS 5 (Designing and Managing Organizational Training

OIS 322 Designing and Managing Organizational Training (3 3 credits)

OEIS 6 (Communications Technologies)

OIS 341 Networking Technologies (3 credits)

OEIS 7 (Cases in OEIS)

OIS 415 Cases in End-User computing (3 credits)

OEIS 8 (Information and Media Management)

OIS 331 Technical Writing for End-user Information Systems (3 4 credits)

OEIS 9 (Special Topics)

OIS 461 Special Topics (groupware, Internet/WWW, etc.) (3 credits)

OEIS 10 (Business Process Redesign)

OIS 351 Microcomputer Troubleshooting and Maintenance (3 credits)

OEIS 11 (Internship)

OIS 471 Internship ( 3 credits) 
and End-user Information Systems (OEIS), was updated not only to include the necessary technical expertise, but to introduce new concepts and competencies graduates would need for today's dynamic workplace. The curriculum was designed to challenge "students to understand their dynamic role from both an organizational viewpoint and the perspectives and needs of the individual they support" (O'Connor, 1996, p. iii). The curriculum for four-year collegiate programs prepares graduates for OIS entry-level positions.

The national curriculum is organized into modules which consist of an 11-course sequence (the first seven of which are core modules and the last four are optional), all with prescribed levels, culminating in an internship. Universities, whether emphasizing liberal arts, business, computer science, education, or technical/vocational disciplines, are encouraged to use this new curriculum as a blueprint (1996, p. 33). This flexibility was particularly attractive to use in a School of Computer Science and Information Systems.

\section{Adapting the National Curriculum to Pace University's four-year OIS Major}

Pace University OIS Curriculum. All students at Pace University take a core curriculum of 60 credits in liberal arts; students in the OIS program carry 39 credits in their major including a three-credit Internship and an additional six credits in programming courses. This leaves 23 elective credits from which students may choose a concentration or minor in other computer, education, business, or liberal arts courses.

Since the OSRA national model curriculum was designed as a template, it was relatively easy for the OIS department to modify the curriculum to our own pragmatic, hands-on, technical model with a side emphasis on soft skills. In a period of one year, the department was able to update courses to fit the national curriculum paradigm, add additional courses, and retain courses that had strengths of their own. Below is a table comparing the national curriculum to the updated Pace University OIS curriculum.

OEIS 1 is an introduction to End-user Information Systems concepts. This course introduces students to the office systems environment, to the impact of technology on worker performance, and to emerging OEIS technologies. Because concepts are introduced in all of the fundamental hands-on application packages--where students, through class projects and team work, apply technological solutions couples with soft skills to various business problems, this was a natural place to answer the needs of OEIS 1.
OEIS 2 continues to survey and review technological solutions for address business needs. This seemed an easy fit for the new course in Multimedia technologies for business solutions.

OEIS 3 covers the planning and design stages of OEIS systems development with particular emphasis upon employee and work group interaction. The OIS curriculum contained a course stressing planning and design with special emphasis on ergonomics (including health and safety issues) in the work place. The OIS course outline matched this module exactly.

OEIS 4 concentrates on implementation and evaluation issues building on concepts and skills developed in OEIS 3. Once again, one of the original OIS courses stressed feasibility studies, planned change issues, and evaluation; no changes were needed other than a change in title.

In an intensive review of the OIS curriculum by the faculty in 1995, it had been decided that OIS majors needed courses in Training and in Networking Technologies. Accordingly, new courses were developed in Designing and Managing Organizational Training as well as in Networking Technologies, thus answering the requirements of OEIS 5 and 6.

Since OIS courses have frequently used the case-study method to improve critical thinking and problem solving, it was natural to adopt $O E I S 7$ as a separate, capstone course integrating the application of concepts, theories, and skills to solving organizational and end-user challenges.

OEIS 8 provides a detailed treatment of information and media management--essentially record keeping. Many of our graduates working in the New York area, however, are called upon to do training materials and technical documentation using selfdeveloped resources--both involving technical writing. For this reason, we felt it important to give students a strong foundation in Technical Writing. Thus, once again, we adjusted the national curriculum to meet our regional needs.

OEIS 9 is Special Topics. OIS has always had a place in the curriculum for special topics used to explore emerging technologies and other unique aspects in the field. Special Topics was a place for introducing such new technologies as HTML and designing websites, WWW, the Internet/Intranet, and groupware--including GroupWise, Lotus Notes, and Group Systems for Windows (GSW). Just as these technologies became useful (often-standard) tools in the workplace, they also became useful tools in the classroom and were either incorporated into other courses or became stand-alone courses. As an example, networking technologies were originally explored as a special topic. Networking Technologies is now a separate course; however, groupware, along with WWW, is 
used as tools supporting some of the other courses including the Technical Writing course and the Cases course.

OEIS 10 presents concepts and methods for business process redesign. While this is an excellent course for students interested in business, the requirements in a School of Computer Science are different. For many years, we have offered a course in Microcomputer Troubleshooting and Maintenance welcomed by industry, students, and other CSIS departments. This course provides all CSIS students the opportunity to learn firsthand the inner workings of a computer. Although the Troubleshooting and Maintenance course is not specifically offered in the national curriculum, we took advantage of the fact that adoptees are encourages to customize the curriculum to make it fit their school and/or department's particular requirements. Therefore, we slotted this course into the OEIS 10 position. This is truly a reality-based course and prepares our students to be experienced troubleshooters and helpdesk agents with “... strong interpersonal skills [offering end-users] immediate help..." (O'Connor, Bronner, and Delaney, 1996, p. 208).

OEIS 11 Internship has always been part of the OIS baccalaureate degree. Pace University has a strong cooperative education program. Students who want to participate have many job sites available to them in the Manhattan and Westchester areas where they can apply the concepts and skills they learned in class to the work place. In addition, students who, because of time constraints, might not be able to participate in the co-op program can apply for supervised internships through the OIS department. These students work for the department in a variety of on-campus positions for a minimum of 90 hours per semester using their education in classrooms and labs.

In summary, we have taken advantage of OSRA's national curriculum's flexibility in updating our own curriculum. We have retained all our application courses (OEIS 1), the Enduser Information Systems courses (OEIS 3 and 4), and the Special Topics course (OEIS 9). We kept our Troubleshooting and Maintenance Course, even though this was not a suggested course in the OSRA curriculum. From the national curriculum, we have adopted and/or further developed courses in Training (OEIS 5), Communications Technologies (OEIS 6), Cases (OEIS 7), and Internship (OEIS 11). We have also revised the Solutions course (OEIS 2) to answer our students' needs. We developed and offered a new course in Technical Writing to satisfy OEIS 8. Thus, we were able to retain eight of our own courses, adopt four new courses from the national curriculum,

\begin{tabular}{ll}
\hline \multicolumn{1}{c}{ Type of Organization } & \multicolumn{1}{c}{ Position Title } \\
\hline $\begin{array}{l}\text { Commercial computer on-line } \\
\text { organization }\end{array}$ & $\begin{array}{l}\text { Systems Engineer } \\
\text { Associate }\end{array}$ \\
\hline $\begin{array}{l}\text { Commercial computer on-line } \\
\text { organization }\end{array}$ & Network Engineer \\
\hline National sports association & $\begin{array}{l}\text { Desk-top Training } \\
\text { Instructor }\end{array}$ \\
\hline PC Learning Facility & $\begin{array}{l}\text { Desk-top Training } \\
\text { Instructor }\end{array}$ \\
\hline Financial Services organization & IS Analyst \\
\hline Government Agency & Revenue Officer \\
\hline PC Hardware organization & $\begin{array}{l}\text { Technical/Help Sup- } \\
\text { port Desk }\end{array}$ \\
\hline Insurance organization & $\begin{array}{l}\text { LAN Network Spe- } \\
\text { cialist }\end{array}$ \\
\hline Brokerage house & LAN Administrator \\
\hline
\end{tabular}

revise one national curriculum course, and create one new course.

\section{Success of the program as shown by employment of graduates}

The graduates' employment is one important component when measuring any effective curriculum program (Moses \& Rehwaldt, 1996, p. 24). Questions to be answered are as follow: Where are the graduates working? What is their entrylevel position and salary? Is that position a stepping-stone for career advancement? The new OIS curriculum, based upon the OSRA model, has successfully responded to these questions.

Pace University OIS graduates have obtained varied professional positions in diverse organizations in Manhattan and Westchester with starting salaries ranging from $\$ 22,500$ to $\$ 35,000$. Below is a partial listing of the type of organizations employing our 1995 - 1997 graduates along with their matching job titles. 


\section{Conclusion}

In revising any OIS curriculum, one of the first requirements is to respond to regional business needs. At our university, a study done in 1992 by one of our faculty members (August) helped us to consider curriculum changes. Our first concern was to meet local industry employment requirements for OIS graduates. It was important that this curriculum develop our students' abilities so that upon graduation they would have relevant marketable skills. This became the impetus for our curriculum changes.

We felt it necessary to use a curriculum that had been validated and was reliable. The OSRA curriculum was validated, has a 15 year history of reliability, and is flexible. It allowed us to tailor it to fit our needs: student employment, regional business requirements, and the CSIS mission statement

"The agile organization knows what is important. It believes in the absolute necessity of change and in the opportunity that resides in adaptability" (Robinson, 1996, p. 19). Thus, Office Information Systems, as a discipline, requires constant updating in order to keep current with organizational change and emerging technologies. This curriculum is preparing our students to meet the challenges of today's agile, team-oriented, technologically supported workplace. It supports the competencies and structures needed in today's changing organization. We are confident that our graduates will be productive citizens in an ever-changing society.

\section{References}

August, A. (March, 1992). "Keeping Curriculum Current: Job Titles and Descriptions in Office Information Systems and their Impact on a University Degree in OIS," Office Systems Research Association (OSRA) Proceedings, 89-110.

Caouette, J. and Lutz, C. (Spring, 1996). "The Status of Model Curricula Development: A Look at the Efforts of ACM, DPMA, and OSRA," Office Systems Research Association (OSRA): Special Curriculum Issue, 14, 1, 30-37.

Davis, G., Dologite, D., Feinstein, D., Gorgone, J., Jenkins, A., Kasper, G., Little, J., Longenecker, H., and Valaich, J., (September, 1995). "IS '95: Guidelines for undergraduate IS curriculum," MIS Quarterly, 19, 341-359.

, Gorgone, J., Feinstein, D. and Longenecker, H. (1995). "IS '95 model curriculum and guidelines for undergraduate degree programs in Information Systems," DPMA.

Fisher, C. and Schwartz, C., (Eds.). (1995). Encyclopedia of Associations, (Vol. 1). Detroit, MI: Gale Research Inc., 779-780.

Jenkins, M. (November 5, 1995). "The continuing impact of technology on education: The challenge and opportunities," ISECON '95
IS Education: Meeting the Challenge of a Global Workplace, Park Ridge, IL: DPMA Education Foundation.

Longenecker, H. and Feinstein, D. (1995). "Implementation of a joint information systems (IS), computer science (CS), software engineering (SE) CORE curriculum compatible with IS '95, CS '91, and SE '91 computing curricula,” ISECON '95 Proceedings, 134.

Merriam, S.B. and Brockett, R.G. (1997). The Profession and Practice of Adult Education: An Introduction. San Francisco: CA: Jossey-Bass.

Moses, D.R. and Rehwaldt, S.S. (Spring, 1996). "The OEIS Model Curriculum: A Template for Implementation," Office Systems Research Association (OSRA): Special Curriculum Issue, 14, 23-29.

O'Connor, B.N. (Ed.) (1996). Organizational and end-user information systems model curriculum. Springfield, MO: Office Systems Research Association.

Bronner, M., and Delaney, C. (1996). Training for Organizations, Cincinnati, OH: South-Western Educational Publishing.

Regan, E.A. (Winter, 1993). "Office Information Systems as a Field of Study and Research," Office Systems Research Association (OSRA): Special Issue-Bring Office Information Systems into Focus, 11, 2, 1-17.

(Spring, 1996). "Organizational and End-User Information Systems: Defining the Field," Office Systems Research Association (OSRA): Special Curriculum Issue, 14, 1, 2-12.

Robinson, D.G. (1996). "Accessing Culture: A Lever for Change," The 21st-Century CEO: Organizational Agility, 8-19. Pace University, 1996 - 1998, Undergraduate Catalog.

Thomas, E. (Fall, 1986). “The Status of Model Curricula Development in Office Systems Education," Office Systems Research Journal (OSRA): Special Curriculum Issue, 5, 1, 59-6 